\title{
BILATERAL DIFFERENCES IN PAPILLARY FINGERPRINT PATTERNS OF LEFT-HANDED AND RIGHT-HANDED INDIVIDUALS
}

\author{
Nadezhda Petrova, Emilia Andreenko \\ Department of Human Anatomy and Physiology, Faculty of Biology, \\ University of Plovdiv, "Paisii Hilendarski", Bulgaria
}

\begin{abstract}
Summary. The aim of the present research work is to study the bilateral differences in the frequency of pattern types of homologous fingers in left-handed and right-handed individuals of both sexes. The sample comprised 379 healthy people, of Bulgarian ethnicity, aged 17-58 years. In the female group, there were 219 right-handers and 53 left-handers, while in males -66 right-handers and 41 left-handers. Fingerprints were taken by the typographic method, in a rotating manner. Papillary patterns were classified into four main types. The data were statistically analyzed. The results showed significant bilateral differences in women (lefthanded and right-handed) in the frequency of ulnar loops of the third finger. In men righthanders, there were significant differences in the frequency of circular patterns of the first and fourth fingers. There were not any differences found in the bilateral comparison of the frequencies of pattern types in the left-handed men.
\end{abstract}

Key words: fingerprint patterns, left-handers, right-handers, handedness.

\section{Introduction}

Dermatoglyphics, as a part of human anthropological characteristics, is concerned with the skin of the palmar and plantar surfaces, where the skin is covered with numerous papillary lines that form certain patterns. The patterns are formed in the third month of embryonic development, but they appear on the skin surface as early as the 18th week of intrauterine development. This very early stabilization of the skin ridges, in the period of the third and fifth month of fetal development, allows an immediate assessment of the influence of various factors in the process of their formation. Papillary lines and patterns do not change with age, they are not affected by environmental conditions, and have a large individual variability; many of their characteristics are passed on by inheritance. For this reason, dermatoglyphics data are widely used by criminologists in dactyloscopy (Wang, 2016, Yen and Guzman, 2007, Edjubov and Bogdanov, 2002), by doctors in the case of questionable paternity (Stark, 2011), in clinical medicine for the diagnosis of some chromosomal diseases (Reed, 1981, Than et al., 1998). In the general investigations of dermatoglyphics patterns there are differences found in the hands: right-left (Kimura and Carson, 1995), gender differences (Nithin et al., 2009, Kapoor and Badiye, 2015, Taduran et al., 2016), territorial (Sváková and Pospíšil, 2001, Scheil et al., 2005) and ethnic differences (Karmakar and Kobyliansky, 2011, Crawford and Duggirala, 1992) and these findings can be useful in anthropology to identify the relationships in different human groups, in studying the bilateral symmetry of the body, etc. There are fewer publications, 
where the bilateral differences in dermatoglyphics patterns of people with different hand dominance have been examined, and this determined our interest in the present study.

The purpose of this study is to compare the basic types of papillary patterns and their frequency at homologous fingers in left-handers and right-handers of both sexes.

\section{Material and methods}

The subject of the study was a set of dermatoglyphics traits in healthy individuals of Bulgarian ethnicity, with no kinship relations. The sample comprised 379 individuals, aged 17-58 years. The female group included 219 right-handed and 53 left-handed women, and the male group - 66 right-handed and 41 left-handed men. There is not advanced selection, the study is transverse and reflects the status of the excerpt. The fingerprints taken belong to university students and their teachers from the University of Plovdiv "P. Hilendarski" from the Faculty of Biology and Faculty of Education. All the students gave the voluntary informed consent to be tested.

Table 1. Demographic data of the sample.

\begin{tabular}{lrrrrc}
\hline \multirow{2}{*}{ Subgroups } & \multirow{2}{*}{ Sample size } & \multirow{2}{*}{ Men } & \multirow{2}{*}{ SD } & \multicolumn{3}{c}{ Age (years) } \\
\cline { 5 - 6 } & & & & minimum & maximum \\
\hline Right-handed women & 219 & 21,33 & 2,96 & 18 & 40 \\
Right-handed men & 66 & 22,93 & 5,02 & 19 & 41 \\
Left-handed women & 53 & 20,98 & 2,08 & 17 & 35 \\
Left-handed men & 41 & 22,80 & 9,31 & 17 & 58 \\
Total & 379 & 21,72 & 4,71 & 17 & 58 \\
\hline
\end{tabular}

The handedness was determined with the Questionnaire of Edinburgh Handedness Inventory, and it was assessed, based on the Laterality Index (Oldfield, 1971). The fingerprints were taken by the typographic method, and they were slightly zoomed to be examined (6 D). Fingerprinting was performed in a passive way, using the rotation method; it started with the fifth finger of the right hand and finished with the fifth finger of the left hand. For a greater reliability, the assessment was performed by two people, independently. Fingerprint patterns were read by the methodology of Cummins and Midlo (1961). Papillary traits were classified into four pattern types - arches (A), ulnar loop (U), radial loop (R) and whorls (W). All varieties of circular patterns went to the group of whorls (twin loop, central pocket loop, lateral pocket loop and accidental). The statistical processing was done with the computer program Excel 2010. The bilateral intergroup differences were determined according to Student's t-test, the level of significance was $\mathrm{p}<0.05$.

\section{Results and discussion}

Table 1 and Table 2 present the comparison made for the papillary fingerprint pattern frequency between the left and right hand of the right-handed and left-handed females. In the two female groups, the most common fingerprint patterns were the ulnar loops, then the whorls, while the least common patterns - the arches and radial loops. The bilateral comparison made between the left-hand fingers and these of the right hand in right-handed women showed a similarity in pattern frequency on the homologous fingers, except for the 


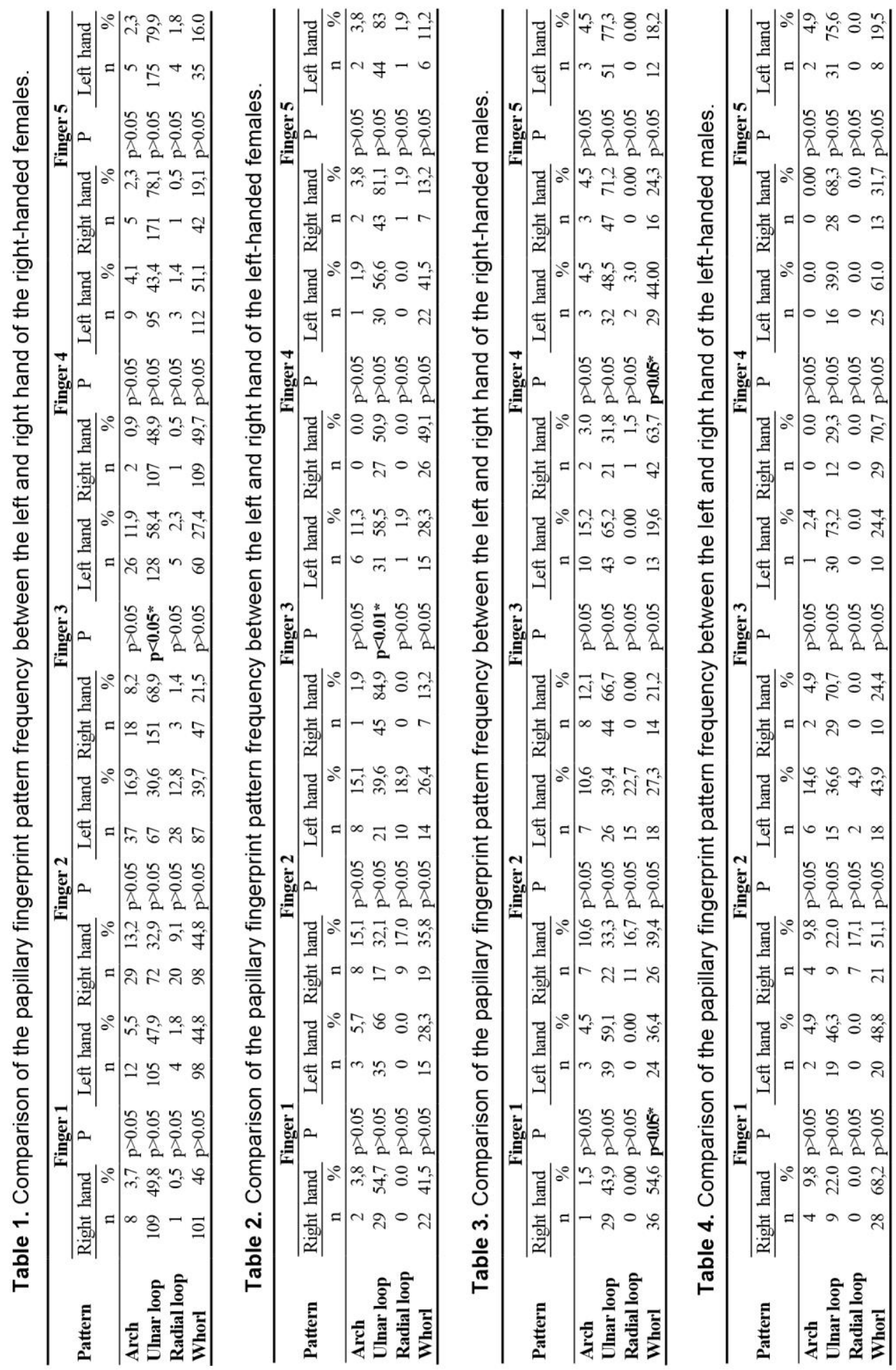


$3^{\text {rd }}$ finger. On this finger of the right hand, the ulnar loops were much more common $(68.9 \%)$ in comparison with the same finger of the left hand $(58.4 \%)-p<0.05$. This tendency was the same in left-handed women. The papillary pattern distribution (loops, whorls and arches), on the symmetrical fingers of both hands, was very similar. There were also bilateral differences in the ulnar loop pattern frequency, found only on the third finger. This frequency was significantly bigger on the third finger of the right hand $(84.9 \%)$, compared to that of the third finger of the left hand $(58.5 \%)-\mathrm{p}<0.05$.

Table 3 and Table 4 present the comparison made for the papillary fingerprint pattern frequency between the left and right hand of right-handed males and left-handed males. Like the female group, in the two male groups tested, the most common fingerprint patterns of both hands were the ulnar loops and whorls, followed by the arches and radial loops. In right-handed men, there were bilateral differences in the ulnar loop pattern frequency, found on the first and fourth fingers. This frequency was significantly bigger on the right fingers, in comparison with the left fingers.

Unlike the right-handed men, such differences were not found in left-handed men. The frequency of fingerprint pattern types, from the first finger to the fifth finger of the right hand, was analogous and matched the frequency of the same (homologous) fingers of the left hand.

Karev, (2008) also found asymmetry in fingerprint pattern frequency between lefthanded and right-handed individuals. He reported more pronounced differences, regarding the ulnar loops, on the first and fourth fingers of right-handed individuals, compared to the homologous fingers of left-handed individuals.

Tornjova-Randelova et al. (2011) also reported a higher percentage of whorls than ulnar loops on the second and fourth fingers of the right hand, in both sexes.

Dermatoglyphics asymmetry has recently become very popular for studying the disorders in neuro-ontogenetic development that occur during the formation of papillary ridges, i.e. in the $3^{\text {rd }}-5^{\text {th }}$ month of prenatal development (Mellor, 1992). Small, random deviations from bilateral symmetrical traits can be a precise measure of development (Palmer, 1996). In many publications, dermatoglyphic asymmetry in fingers is associated with the influence of prenatal stress on pregnant women (King et al., 2009). Higher values show a bigger sensitivity towards early stress conditions (Markow and Wandler, 1986), and they indicate a lower body resistance to harmful external influences (Van Valem, 1962).

The dermatoglyphics assessment, done in this study on papillary fingerprint patterns on the homologous fingers of the right and left hand of males and females, right-handed and left-handed individuals, can contribute to data gathering about the relations examined (bilateral differences) and to their better understanding.

On the basis of our findings, the following conclusions can be drawn:

1. In females from the two groups tested (left-handed and right-handed women), the bilateral comparison in the fingers of the left and right hands shows a similarity in the frequency of fingerprint pattern types, except for the frequency of ulnar loops in the third finger. In both, right-handed women and left-handed women, the right finger has significantly more ulnar loops than the left finger.

2. In left-handed males, there are no differences found in the bilateral comparison of the frequencies of fingerprint pattern types.

In right-handed men, the most pronounced bilateral differences are found. The frequency of whorls patterns on the first and fourth fingers is significantly greater in right fingers than in left fingers. 


\section{References}

Crawford, MH., Duggirala, R. (1992). Digital dermatoglyphic patterns of Eskimo and American populations: relationships between geographic, dermatoglyphic, genetic, and linguistic distances. Hum. Biol., 64, 683-704.

Cummins, H., Midlo, C. (1961). Finger prints, palms and soles. An introduction to dermatoglyphics.Philadelphia, Blakinstone. Reprinted: New York. Dover., 319.

Edjubov, L., Bogdanov, N. (2002). Introduction in papillaroscopy. - V: Papillary rewiews: Identification and determining characteristics of personality (dactyloscopy and dermatoglyphics). 11 -34. [ in Russion]

Doreen, K., Carson, M. (1995). Dermatoglyphic asymmetry: Relation to sex, handedness and cognitive pattern. Personality and Individual Differences, 19(4), 471-478.

Karev, GB. (2008). Finger dermatoglyphics and their asymmetry in Bulgarian right-, mixed- and lefthanders. Anthropol Anz., 66(3), 281-93.

Karmakar, B., Kobyliansky, E. (2011). Finger and palmar dermatoglyphics in Muzeina Bedouins from South Sinai: a qualitative study. Pap. Anthropol, 20, 146 -159.

King, S., Mancini-Marie, A., Brunet, A., Walker, E., Meaney, MJ., Laplante, DP. (2009). Prenatal maternal stress from a natural disaster predicts dermatoglyphic asymmetry in humans. Dev Psychopathol., 21(2), 343-353.

Markow, TA., Wandler, KR. (1986). Fluctuating dermatoglyphic asymmetry and the genetics of liability to schizophrenia. Psychiarr., 19, 323-328.

Mellor, CS. (1992). Dermatoglyphic evidence of fluctuating asymmetry in schizophrenia. British Journal of Psychiatry, 160, 467-472.

Neeti, K., Ashish, B. (2015). Sex differences in the thumbprint ridge density in a central Indian population. Egyptian Journal of Forensic Sciences, 5(1), 23-29.

Nithin, MD., Balaraj, BM., Manjunathax, B., Shashidhar, CM. (2009). Study of fingerprint classification and their gender distribution among South Indian population. Journal of Forensic and Legal Medicine, 16(8), 460-463.

Oldfield, RC. (1971). The assessment and analysis of handedness: the Edinburgh inventory. Neuropsychologia, 9(1), 97-113.

Palmer, AR., (1996). Waltzing with asymmetry. BioScience, 46, 518-532.

Reed, T. (1981). Dermatoglyphics in medicine - Problems and use in suspected chromosome abnormalities. Am J Med Genet, 8, 411-29.

Scheil, HG., Schmidt HD., Baltova, S., Djordjevic, D., Vulpe, C., Siváková, D., Efremovska, L. (2005). Dermatoglyphic studies in Eastern and South-Eastern Europe. Anthropol. Anz, 63, 393 399.

Stark, MM. (2011). Clinical forensic medicine: a physician's guide. Humana press. 473.

Sváková, D., Pospíši, M. (2001). Dermatoglyphic analysis of Habans (Hutterites) from Slovakia. Anthropol. Anz., 59, 355-363.

Taduran, RG., Tade, AK., Escalona, NA., Townsend, GC. (2016). Sex determination from fingerprint ridge density and white line counts in Filipinos. Homo, 67(2), 163-171.

Than, M., Myat, KA., Khadijah, S., Jamaludin, N., Isa, MN. (1998). Dermatoglyphics of Down's syndrome patients in Malaysia comparative study. Anthropol. Anz., 56, 351-365.

Tornjova-Randelova, S., Paskova-Topalova, D., Yordanov, Y. (2011). Dermatoglyphic in anthropology and medicine. - Own studies with individuals with different disorders. Sofia, Academic publishing house "Marin Drinov", 94 - 158. [in Bulgarian]

Van Valem, L. (1962). A study of fluctuating asymmetry. Evolution, 16, 125-42.

Wang, JZ. (2016) Quantitative Comparison of Partial-Full Fingerprints at Scenes Using a Hand-Held Digital Device: A Quasi-Experimental Design Study. J Forensic Investigation, 4(2), 1-6.

Yen, R., Guzman, J. (2007). Fingerprint image quality measurement algorithm. J Forensic Identif., $57,274-287$. 


\title{
BILATERALNE RAZLIKE PAPILARNIH LINIJA KOD DESNORUKIH I LEVORUKIH OSOBA
}

\author{
Nadezhda Petrova, Emilia Andreenko
}

Sažetak. $\quad$ Cilj ovog istraživačkog rada je proučavanje bilateralnih razlika učestalosti glavnih tipova papilarnih šara homolognih prstiju kod levorukuh i desnorukih osoba oba pola. Uzorkom je obuhvaćeno 379 zdravih osoba, bugarskog etničkog porekal starosti 17- 58 godina. U ženskoj grupi bilo je 219 desnorukih i 53 levorukih osob, dok je u muškoj grupi bilo 66 desnorukih i 41 levorukih osoba. Otisci prstiju uzeti su topografskom metodom rotacije. Papilarne šare klasifikovane su u četiri glavne grupe. Podaci su statistički obrađeni. Rezultati ukazuju na značajne bilateralne razlike kod žena (levorukih i desnorukih) u učestalosti ularnih petji kod trećeg prsta. Kod desnorukih muškaraca, uviđene su značajne razlike u učestalosti kružnih šara prvog i četvrtog prsta. Kod levorukih muškaraca nisu uočene razlike bilateralne komparacije učestalosti tipova papilarnih šara.

KIjučne reči: šare otisaka prstiju, desnoruke osobe, levoruke osobe, rukost 